\title{
Expanding the precautionary principle
}

\section{B Pless}

\section{Injury prevention and the precautionary principle}

"As to diseases, make a habit of two things-to help, or at least do no harm" (Hippocrates, The Epidemics)

"When an activity raises threats of harm to human health ..., precautionary measures should be taken even if some cause and effect relationships are not fully established scientifically" (Wingspread conference, 1998)

A fundamental teaching in clinical medicine is primum non nocere-first do no harm-that is, when physicians face choices between uncertain benefits and possible harm, they must err on the side of safety.

In environmental public health a similar edict has emerged. The "precautionary principle", popularized 10 years ago in relation to environmental safety, is now increasingly accepted. It asserts that when there is suspected harm and the scientific evidence is inconclusive, the prescribed course is precautionary action. It is intended to apply when the harm is "serious, irreversible, and cumulative". The precautionary principle is the flip side of "risk assessment"-the current coin of the realm-which requires safety advocates to provide convincing evidence for harm. By implication, if they fail to do so, possibly dangerous products or practices will remain in place.

A popular summary of the principle arose from a UN conference and is found in the 1992 Rio Declaration: "Nations shall use the precautionary principle to protect the environment. Where there are threats of serious or irreversible damage, scientific uncertainty shall not be used to postpone cost-effective measures to prevent environmental degradation". ${ }^{1}$

The principle initially applied only to toxic substances but has since broadened to include other environmental hazards. It struck me that there is no reason why it should not be extended further to include much of injury prevention. Because I dislike clichés like "paradigm shift" in this case I am simply proposing that the paradigm be expanded.

I was reminded of the precautionary principle when I thought about several of the papers appearing in this issue. My homework led to a number of relevant publications $^{2-5}$ and many interesting websites (for example, information on biotechnology ${ }^{6}$ and Rachel's Environment and Health News $^{7}$ ). Why, I mused, should the prevention of physical injuries to humans not be viewed in the same light as the harm toxic substances may do to the environment? The banning of phthalate plasticizers in toys was one step in this direction and it is interesting that the Danish Environment Agency was able to justify the ban based on the precautionary principle while the Consumer Product Safety Commission did the same but "only after a costly, time-consuming quantitative assessment". ${ }^{4}$

In one of the papers I turned up, the author wrote, "Public health advocates around the world have increasingly invoked the precautionary principle as a basis for preventive actions". ${ }^{3}$ (So far so good.) He continued, "This has been particularly true for environmental and food safety issues, in which the ... principle has moved from being a rallying cry for environmental advocates to a legal principle embodied in international treaties". (Better still because it is now a matter of law in Germany and Sweden and applies to many international treaties.) The bad news is that the precautionary principle remains almost entirely restricted to the "environment".

Thus, although the precautionary principle is visionary, its narrow application is short sighted. Read it again and ask why the same fundamental arguments should not apply beyond what is conventionally meant by "the environment". Pedestrian and cyclist safety are excellent examples as is the safety of occupants of vehicles that roll over (Rivara et al, p 76). Similarly, home (Driscoll et al, p 15; Lipscomb et al, p 20) and workplace safety (Loomis et al, p 9) illustrate the point nicely.

Or consider cell phone use in cars, where there is still debate about what the evidence tells us. ${ }^{8-10}$ Under the precautionary principle the benefit of any doubt about their harmfulness would prompt policy makers to enact laws to prevent their use (as many countries have now done). Likewise, although there is less disagreement about their harmfulness, we would not continue to permit children's clothing with drawstrings or baby walkers to be marketed. There would be no endless delays while the dangers were proven with $95 \%$ certainty. There would be no pondering how many injuries or fatalities there must be before regulatory agencies are required to act. Nor would there be undue consideration given to the economic consequences to the manufacturer or retailer of removing a harmful product from the marketplace.

In each of these examples, if the precautionary principle were applied, it would be up to the manufacturer to assure the regulatory body that the product was harmless. This is essentially the standard now applied in most countries when a pharmaceutical company wishes to market a new drug. Why should other products be treated any differently?

In most countries regulatory bodies have both the power and the responsibility to put the principle into practice. There follows a heavy obligation to exercise those powers properly. Failure to do so may lead to serious legal consequences. When, for example, the Red Cross in Canada failed to screen donor blood for HIV and hepatitis C after the means to do so were available, civil suits in the order of hundreds of millions of dollars were filed and criminal charges followed. The same reasoning could apply to any instance where harm can reasonably be anticipated and thus prevented.

The importance of extending the principle to include many other safety issues was reinforced when I read two recent papers on risk factors and the burden of disease. These papers made me wonder (yet again) why injuries have still not appeared more prominently on the radar screens of most policy makers. One, by Ezzati et al aimed to "estimate the contributions of selected major risk factors to global and regional burden of disease in a unified framework" ${ }^{11} \mathrm{Al}$ though the term "disease" is used, the background statement refers to the analysis of risks as the "key for preventing disease and injury" (italics are mine). Yet, somehow, the authors lost track of injuries and concentrated on disease, even though one of the 26 selected risk factors was alcohol.

Commenting on this report, Yach noted that "The mystery is in understanding why the public-health community continues to give such low priority to effective preventive measures, especially for chronic diseases".${ }^{12}$ I disagree: the real mystery is how one can comment on this topic and say so little about injuries? In light of what is known about their position in the sad lists of major killers, how can this be? More remarkably, how can this originate from someone associated with the World Health Organization so soon after the publication of its superbly documented report on violence? ? $^{13}$ 
In search for balance on this undoubtedly contentious issue, about which I encourage debate by our readers, there are other viewpoints to consider. In addition to the traditional position of those who favour risk analysis type evidence, there are epidemiologic issues. This journal makes no bones about favouring papers built on epidemiologic data. But it is fair to ask, as Appell does, "Is the precautionary principle consistent with science, which after all can never prove a negative?" ${ }^{\prime 5}$ Tukker observed that "parties on both sides simply caricature each other's position: precaution would lead to a standstill of all innovation . . . and risk assessment neglects ignorance" ${ }^{2}$ He argues, however, that "risk assessment and precaution are not mutually exclusive". But he acknowledges that epidemiology has its limits in the reconciliation process for pragmatic and fundamental reasons

The pragmatic is the difficulty in producing conclusive cause-effect evidence. The fundamental is the largely retrospective nature of many epidemiologic studies when the problem for prevention requires looking forward. Thus it is difficult for epidemiology "to judge the need for preventive action". (Although I disagree, the point is worthy of discussion.) And Goldstein asserts "At its core, the precautionary principle contains many of the attributes of good public health practice, including a focus on primary prevention and a recognition that unforeseen and unwanted consequences of human activities are not unusual". ${ }^{3}$

In the final analysis, the perception of injuries by policy makers may well be altered if the precautionary principle were expanded as I urge it should be. The burden rests as heavily on researchers as policy makers, however. The President of the American Association for the Advancement of Science challenged scientists "to define a new social contract" . . . and make a commitment "to devote their energies and talents to the most pressing problems of the day, in proportion to their importance, in exchange for public funding". ${ }^{5}$ Nevertheless, the buck has to stop somewhere and as Yach concludes, "Putting prevention first requires political courage ...". ${ }^{12}$

Injury Prevention 2003;9:1-2

\section{Author's affiliation}

I B Pless, Montreal Children's Hospital and McGill University, Montreal, Canada
Correspondence to: Professor Pless; barry.pless@mcgill.ca

\section{REFERENCES}

1 United Nations Conference on Environment and Development. Rio declaration on environment and development 31 ILM 874. New York: United Nations Press 1992.

2 Tukker A. The precautionary principle and epidemiology. J Epidemiol Community Health 2002:56:883-4.

3 Goldstein BD. The precautionary principle also applies to public health actions. Am J Public Health 2001;91:1358-62.

4 Kriebel D, Tickner J. Reenergizing public health through precaution. Am J Public Health 2001;91:1351-4.

5 Appell $\mathbf{D}$. The new uncertainty principle. Scientific American 2001 (January): 18-19. 6 www.biotech-info.net/precautionary.html.

7 Rachel's Environment and Health News. Available at: http://www.rachel.org/.

8 Redelmeier DA, Tibshirani RJ. Association between cellular-telephone calls and motor vehicle collisions. N Engl J Med 1997;336:453-8.

9 Anonymous. Driven to distraction: cellular phones and traffic accidents [editorial]. Can Med Assoc J 2001;164:1557.

10 Therien EJ. The accidental cell phone user [letter]. Can Med Assoc J 2001; 165:397.

11 Ezzati M, Lopez AD, Vander Hoorn S, et al. Selected major risk factors and global and regional burden of disease. Lancet 2002:360:1347-60

12 Yach D. Unleashing the power of prevention to achieve global health gains. Lancet 2002;360:1343-4

13 Krug EG, Dahlberg LL, Mercy JA, et al, eds. World report on violence and health. Geneva: WHO, 2002 